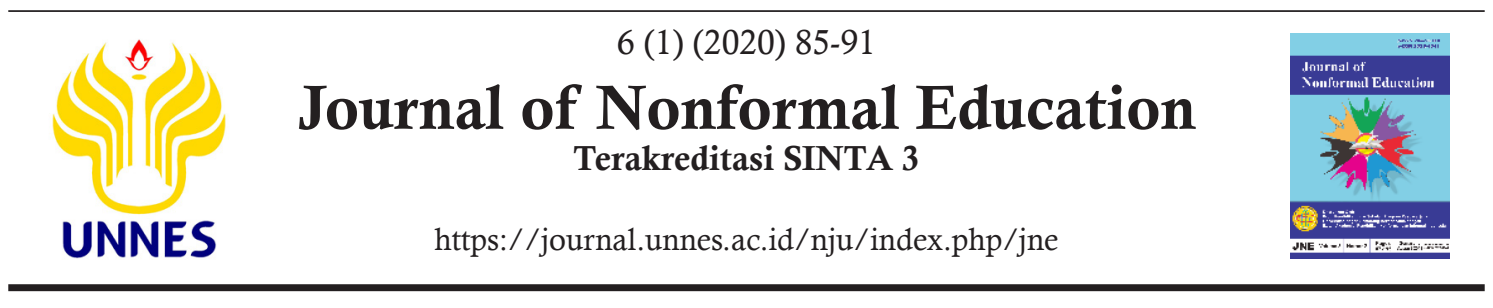

\title{
Optimization of Community Reading Garden Management in Improving Reading Culture
}

\author{
Serafin Wisni Septiarti $\bowtie$, Sujarwo Sujarwo, Fitta Ummaya Santi, \\ Tristanti Tristanti
}

DOI: http://dx.doi.org/10.15294/jne.v6i1.23479

Universitas Negeri Yogyakarta, Indonesia

\section{History Article}

Submitted 22 December 2019 Revised 24 January 2020

Accepted 4 February 2020

\section{Keywords}

Community Reading; TBM Management; Improving Reading Culture

\begin{abstract}
TBM is more accurately called a reading facility in the middle of the community (community-based library) and is managed simply, and independently by the community concerned. This action research aims to (1) describe the management pattern of Community Reading Gardens as part of Omah Passionaon empowerment programs; (2) Explain the optimization of TBM management in its efforts to improve reading culture. Action research with a focus on optimizing TBM management is carried out using a diagnosis, planning, implementing action and evaluation model with Omah Passinaon managers as research subjects. Data or information is collected by interviewing techniques such as FGDs, observations on aspects of program management, activities to obtain a comprehensive picture of the potential, problems, needs for improvement and forms of action to optimize TBM management. The results of this study indicate that (1) TBM management emphasizes the competence of capable and skilled managers in building public awareness of the importance of reading culture, as well as the realization of TBM that has community appeal as a source of information in Bejiharjo tourism area. (2) Actions for optimizing TBM management in research include (a) Raising public awareness of reading fondness at Omah Passionaon, (b) partnerships with academics, universities, and private parties, (c) mentoring for pioneering TBMs that attract public interest in reading, (d) evaluation. TBM management can be effective must have partnerships from private or government institutions, besides that the manager also has good competence. The benefit of this research is to provide awareness to the community to read and motivation for TBM managers to seek partnerships with private and government institutions.
\end{abstract}

Correspondence Author:

E-mail: swisni@uny.ac.id
p-ISSN 2442-532X e-ISSN 2528-4541 


\section{INTRODUCTION}

Many aspects of human life have changed because of rapid technological developments. Literacy through social media like Facebook, Instagram, WhatsApp, line as evidence of the development of science and technology is not impossible that the development of science and technology has a positive impact but also negative (Agyeman, 2016). Society tends to use information technology not to improve reading skills, interest in reading but for recreational things, entertainment that is less healthy or even for interests that disturb the stability of society (Oxenham, 2017). Besides, the interest in reading that can develop wider knowledge is no longer a priority for the community, so the culture of reading becomes difficult to realize. Meanwhile universally reading is the door to open the world of intelligence to quality and prosperous life (Tegmark, 2017). One of the media to cultivate reading is Taman Bacaan Masyarakat.

The government through formal, informal and non-formal education service institutions continues to make efforts so that people have better reading skills so that there is a change in the way of thinking that requires people to be literate (Febrianti \& Irianto, 2017). Based on the 2013 Human Development Report, Indonesia's Human Development Index in terms of the quality of education including reading points was ranked 122 out of 170 countries (Courtay, 2012). Abdulkerim and Remzi (Karadeniz \& Can, 2015) define reading are seeing and understanding the contents of what is written (by speaking or only in the heart), spelling or reciting what is written, saying, knowing, predicting, calculating, and understanding. According to UNESCO in 2012, Indonesia's reading interest index had only reached 0.001 . That is, in every 1,000 Indonesians, there is only one person who has an interest in reading (Courtay, 2012).

Data from the 2012 Central Statistics Agency on socio-cultural indicators shows that the population of Indonesia who makes reading as a source of new information is around $17.66 \%$, while those who watch television are $91.68 \%$ and listen to the radio 18.57\%(Badan Pusat Statistik, 2016). This shows that Indonesia has not made reading a culture. Harvey and Goudvis (2017) describe reading as thinking and understanding. While reading means that the reader tries for a specific purpose, to understand texts written by the author for specific communication purposes. Some of the benefits of reading according to (Yunus, 2018) are, broadening insight, sharpening ideas, increasing one's creativity.

Reading activities can be done anytime and anywhere. Reading places namely public places, public reading places, semi-public places, domestic meeting places, and private places (Aelbrecht, 2016). Reading activities indicate that reading is a mild and enjoyable activity so that everyone can do it. One form of reading services to the community in the form of Community Reading Gardens (TBM).

Bejiharjo as a tourist destination has a great opportunity in growing the economic level for its people. In addition to fostering natural attractions, Bejiharjo also presents an institution as a place of the informal learning community, Omah Passinaon. Omah Pasinaon is a house of community learning as a form of innovation to address fears of waning values/local wisdom and to maintain cultural integrity in the Special Region of Yogyakarta. Omah Passinaon as a nonformal learning place has made the surrounding community have knowledge and skills. This is because many programs have been provided to the surrounding community. When the program is finished, the community is busy again with their daily activities such as working as a housewife or as a farm labourer. The pattern of life like this if left on continuously even though there is an institution as a place of learning, the community's knowledge will not increase, the community will always depend on the help of other parties.

TBM has provided services to the public to access information through reading. However, its existence is less attractive to the community as a place to increase knowledge. The community does not feel the need for reading activities. In addition to the lack of community motivation in reading, TBM management needs to be a concern. Good TBM management will foster community interest in reading and learning. TBM developed by Omah Passinaon Bejiharjo is not optimal because; (a) the existence of TBM does not yet have an attraction to be visited by the community, (b) management still does not refer to community learning service standards, such as programs, activities, management resources, collection development, so there is no management update yet.

Much research has been done related to Community Reading Gardens, namely research on the management of Community Reading Gardens (Suwanto, 2017) that the management of Community Reading Gardens is following library management. Research conducted (Pramudyo, et al., 2018) which states that the innovations of Taman Bacaan Masyarakat activities include tu- 
toring, discussion together, prayer, photography, Monday performances, t-shirt screen printing, story boxes, colouring, watching together, gymnastics and competitions. Research related to the role of community reading parks was also conducted (Maulida, 2017) who showed that community reading parks play an important role in developing reading interest. Although a lot of research has been done in Community Reading Gardens, research related to optimizing Community Reading Gardens has not been done. Therefore, this research focuses on optimizing Community Reading Gardens in improving the reading culture at Omah Pasinaon.

\section{METHODS}

Action research is widely introduced by experts as a research method that simultaneously does something for a particular purpose. Action research according to Ernest T. Stringer (Denskus, 2008) will run according to the stages expected in a collaborative form if there is a relationship, communication, participation, and inclusion in the principle of work (intervention). The stages in action research are the stages of identifying learning needs, planning, implementation and evaluation. In some action research references (action research) are often called participatory action research. The scheme in the action research process according to (Soh, et al., 2011) as follows:

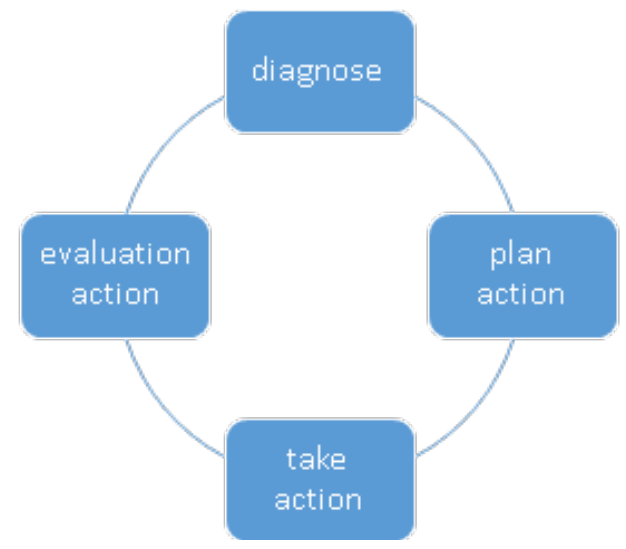

Figure 1. Action research scheme

This action research was carried out through four stages which were expected to increase awareness, attitudes, and knowledge of the importance of reading through the TBM program. (1) The diagnosis stage begins with an analysis of the situation about TBM management in Omah Passinaon which is not yet optimal. Activities are carried out through Focus Group Discussions. Through this FGD the researcher explores the activities of the target group in building joint commitment and identifying the problems faced. (2) Planning that will be applied as an effort to improve the learning process to realize results/ products, packaging and business management. (3) Implementation of the design of corrective actions to be carried out by partners in terms of increasing ability, human resource skills in managing developing TBM. At this stage, the research team was still an observer collaborating with TBM management while carrying out plans for further activities. (4) Evaluation action, stages to jointly participate actively in reflecting or dialogue with one another to find solutions to difficulties, weaknesses of the learning process in previous actions.

Data collection techniques that will be carried out are (a) Interview, a method of collecting data by asking questions directly to the research subjects. The research subjects in this action research are TBM managers, (b) Observation, in this action research will be carried out in a participatory manner by the research team so that the development and assistance plan can be following the needs of the community itself, (c) FGD (Focus Group Discussion), this technique will be carried out at the beginning of the program activities to identify the problems and needs of the community in managing TBM.

The analysis was carried out at the dialogue stage through active communication involving the togetherness of the research team as observers, resource persons and target groups. All data or information collected during the process is classified for meaningful interpretation.

\section{RESULTS AND DISCUSSION}

\section{TBM Management Model}

According to (Arifin \& Marlini, 2017) Taman Bacaan Masyarakat is an institution or service unit of various reading material needs that are needed and useful for each person or group of people in the village or the TBM region to increase reading interest and create a reading culture. Taman Bacaan Masyarakat is not a library that must meet the national library standards, such as collection standards, facilities and infrastructure standards, library service standards, library staff standards, implementation standards and management standards (Lusiana, et al., 2019). Taman Bacaan Masyarakat is more accurately called a reading facility that is in the middle of the community (community-based library) and is managed simply, and independently by the community concerned. 
Becoming a separate issue when community service institutions have a fondness for reading in the form of libraries, reading parks to reading places have not fully attracted the public to come to visit community reading parks and have a culture of reading. One of the things done as a form of reflection on improving service quality is the management of the reading park which is less than optimal. Optimization of community reading park management is the focus of this research because through this research efforts to develop an interest in reading, especially in tourist areas, are important to do.

The management of TBM in a tourism village requires the support of many parties both from the management, the surrounding community and visitors of the tour. Reading activities in the tourism village have not shown its activity. That is because the facilities owned by TBM have not met the expectations of the reading community of the various organizations managed by Gua Pindul tourism villages such as Youth Organization, PAUD, Tutoring and Omah Pasinaon, all of them do not yet have complete facilities in TBM management. The facilities referred to are books which are the main material for the reader. The books are still limited in number and not following the target, so there is a need to procure books following the target group.

Related to other facilities such as infrastructures which include buildings, bookshelves, tables and chairs as well as administrative staff are not an obstacle if they are not optimally available. This is because TBM is more defined as a reading facility that is in the middle of the community (community-based library) and is managed simply, and independently by the community concerned. Therefore, in the management of TBM does not have to have management standards as library standards. The important thing that must be fulfilled is the active participation of the community in managing TBM together (Anna, et al., 2020).

The pattern is in line with what is being initiated by TBM in the Pindul tourist village, especially in Omah Pasinaon. The potential is owned by the people who are learning by utilizing the natural potential. Besides, the location allows for the development of TBM and attractions that attract tourists to come to Pindul Cave. With this potential, it has become a strength in the development of TBM. The purpose and objectives of pioneering TBM in Omah Passinaon are (1) as a place to collect or gather information from various sources, in the sense that TBM has a continuous activity to lead information, (2) as a place to process library materials with cataloguing methods either manually or technology so that collections are easy to find and use, (3) as a centre for information, learning resources, research, and other scientific activities, as well as providing services to users such as reading, borrowing, easily and inexpensively.

The number of tourists visiting is a separate reason to start TBM. The leisure time that tourists have while waiting their turn to go down the cave or rest after down the cave can be utilized by accessing various information from TBM. Optimizing the management of TBM in Bejiharjo tourism village is carried out through various actions so that TBM can be used optimally. From these actions are following the targeted indicators.

The initial action taken is to foster awareness of administrators of reading culture (Rahmatillah, 2018). Administrators who have a reading awareness are expected to have a positive influence on the surrounding community through various activities such as providing a comfortable place to read (Rahayu et al., 2019). The name TBM also greatly influenced the community to be interested in visiting it. Therefore, the name Tourism Reading Corner is a name formed to dub TBM that is being pioneered in the tourist village. The name TBM is intended to be easily understood by the community and also attracts tourists to visit and carry out reading activities (Rahayu, 2010).

Although the community reading activity has not been maximized, there is already a sense of public awareness of the importance of reading activities. The ability of managers to optimize TBM begins with the provision and arrangement of interesting books according to the needs of the community. Thus, it is expected to bring up people's interest in reading both of their own volition or the support of parents and surrounding communities. Reading fondness that has been formed later will bring up the reading culture (Selden, 2016).

The pioneered TBM already has a management structure consisting of chairpersons, secretaries, treasurers and other staff and each position has its respective duties in its management. This is following TBM management guidelines, namely (a) managers who have a caring attitude in inviting the community to read, help to serve the community in finding reading material and guiding the community in reading. (b) TBM managers can disseminate the promotion of reading material and also the existence of TBM itself either through direct interaction or through brochu- 
re media. (c) TBM managers are also able to analyze the needs of the surrounding community so that the reading material provided is following the needs of the reader (Indriyani, 2017).

In terms of partnerships, managers can establish partnerships both with government agencies and private institutions. Partnership with an institution that is conducting planning procurement of books from France. This is because there are students who are doing research related to Outside School Education in the tourist village of Bejiharjo and one of the focuses is the TBM study. Partnership with the private sector is the existence of book donors from various private institutions. The number of varied reading material will increasingly attract people to read because it is not boring (Grabe, \& Stoller, 2019). TBM managers must have the ability to find information to develop TBM through various events such as exhibitions. The active TBM in participating in the organization's activities will make it easier for the community to get to know TBM (Rohman, 2019).

The diagnoses or problems that have been collected through the FGD are (a) Community Reading Gardens to be the choice of the unit to be developed through this action research in addition to because TBM is a means of educating the nation, has management resources that are ready to go forward and develop as well, (b) TBM which still pioneering in several aspects requires action to strengthen institutions in addition to the synergy between programs or activities contained in Omah Passinaon also to improve human resource management as an effort to optimize TBM to improve the reading culture of the community, especially visitors to the Bejiharjo tourist village.

The results obtained from the optimization of TBM management actions are (a) TBM managers have the ability and skills in building public awareness of the importance of reading culture, (b) the realization of TBM that has community appeal as a source of information and educational entertainment activities in the tourist area of Bejiharjo, (c) the establishment of an integrated, integrated and synergistic (developing together) TBM and in the program, Omah Passinaon activities.

\section{Implementation of TBM Management Optimi- zation Actions}

In carrying out the TBM program it is necessary to have good management so that what is targeted can be achieved. Management organization is important because it can divide tasks according to the ability of each board. The mana- gement consists of the chairman, secretary, treasurer and staff. Each board must have its responsibilities so that there is no double task (Fayol, 2016). Management of TBM organized by tourism agency is not optimal. From observations made it can be explained that each organization does not yet have a good management structure. The activity was still directed by several people so that the tasks of each management had not yet been seen. Therefore, there is a need for guidance related to management which must be followed by all TBM management (Deng, 2018).

This activity was attended by all TBM managers from each organization (youth organization, tutoring, PAUD and Omah Pasinaon). The activity of building partners is important to be able to do well because through partners the TBM will conduct mutually beneficial cooperation. TBM partnership can be interpreted as finding and finding parties to work together between two or more parties, individuals or institutions in managing one or several activities organized by TBM based on equality, openness and mutual benefit (providing benefits) (Hoerniasih, 2017). The steps in building partners are: (1) assessing internal preparedness; the existence of activities that are appropriate to be exposed or carried out, the need for cooperation for several reasons, for example; the broad scope of activities and impacts, because TBM cannot carry out its activities, (2) identifying potential partners; selection of parties who have the same vision so that partners believe that the collaboration with Taman Bacaan Masyarakat will gain added value through the cooperation offered, (3) assessment and form of cooperation; What benefits will be gained in the short and long term by both parties, (4) compilation of proposals and submission strategies;

From the various steps mentioned above, it is necessary to understand things in starting a business or starting to manage TBM, namely: (1) courage to start a business, (2) identification of business opportunities that are following their potential, (3) business analysis, namely courage to get out of standard practices with due regard to consumer tastes, and (4) management of business results to support TBM activities. Meanwhile, to develop a business in managing TBM can carry out activities as follows: (1) event organizer: book exhibition, competition for children, etc. with a prediction of $30 \%-40 \%$ profit, (2) advertising and print media Bureau with a predicted $20 \%$ profit, (3) distributor of books with a predicted profit of 20\%, (4) design and printing service with a predicted profit of $35 \%-50 \%$, (5) culinary with profit prediction of $35 \%-50 \%, 6$ ) convection pre- 
diction of $30 \%-35 \%$ and the last is according to the opportunities and local potential possessed.

Assistance activities continue to be pursued by the researchers through communication with the tour village manager and also direct communication with TBM management. Communication is done via SMS or WhatsApp messages. Academic assistance through sharing experiences in managing TBM, managing and developing human resources as well as sharing knowledge in organizing places, TBM facilities and the process of integrating synergistically between programs and activities periodically.

Evaluation activities are carried out after the action is carried out by the trainees through the question and answer method and observation sheets. From the results of the evaluation, some management experienced difficulties in establishing partnerships with both private and government institutions. Therefore, further action is needed to optimize TBM management which is focused on establishing partnerships.

Optimization as carried out in the actions of this study, there are several meanings of action as follows, (a) provide motivation and images to the community through socialization about the importance of reading to get quality of life, (b) the management is always looking for information about the needs of reading materials needed by the community so that it can provide varied books and following community needs, (c) establish cooperation, partnerships or collaborations with various parties that can add to the collection of reading books in TBM, (d) providing services to the community in an integrated manner between TBM and other supporting activities at Omah Passinaon based on potential, local skills or through activities to express the culture of the local community, (e) innovations in TBM activities that synergize with village tourism activities such as entertaining but still educational competitions.

\section{CONCLUSION}

The optimization of TBM management through training and assistance as a process of action in this study can be concluded. In managing a pilot TBM, initial activities are needed in the form of a process of public awareness of the importance of reading activities to improve the quality of life. The competence of TBM managers can be understood to obtain an optimal management model. Motivation and skills in increasing synergy, attractiveness, integrated activities, variations and arrangement of reading books become part of the commitment in developing TBM for visitors to the Bejiharjo tourist village. The partnership model becomes the choice of TBM with the government, private institutions and academics to strengthen community learning service institutions.

\section{REFERENCES}

Aelbrecht, P. S. (2016). 'Fourth places': the contemporary public settings for informal social interaction among strangers. Journal of Urban Design, 21(1), 124-152. https://doi.org/10.1080/1357 4809.2015.1106920

Agyeman, E. A. (2016). Influence of social media on literacy development among junior high school pupils in the Asante-Akim South District (Doctoral dissertation, University of Education, Winneba).

Anna, N. E. V., Mannan, E. F., \& Srirahayu, D. P. (2020). Evaluation of the role of society-based library in empowering Surabaya city people. Public Library Quarterly, 39(2), 157-169.

Arifin, F., \& Marlini, M. (2017). Pemanfaatan Taman Bacaan Masyarakat Tanah Ombak di Purus III Padang sebagai Sumber Belajar. Jurnal Ilmu Informasi Perpustakaan dan Kearsipan, 5(2), 21-32. Retrieved from http://ejournal.unp.ac.id/index.php/iipk/article/download/8423/6490

Badan Pusat Statistik. (2016). Profil Rumah Tangga Fakir Miskin-Miskin Provinsi Daerah Istimewa Yogyakarta. Yogyakarta: BPS.

Courtay, R. de. (2012). United Nations Decade of Education for Sustainable Development (2005-2014) Shaping. United Nations Educational, Scientific and Cultural Organization. Retrieved from http://unesdoc.unesco.org/images/0021/002166/216 606e.pdf 102

Deng, M. (2018). Challenges and Thoughts on Risk Management and Control for the Group Construction of a Super-Long Tunnel by TBM. Engineering, 4(1), 112-122. https://doi. org/10.1016/j.eng.2017.07.001

Denskus, T. (2008). Review: Ernest T. Stringer. Action Research, 10(1). https://doi.org/10.17169/fqs10.1 .1188

Fayol, H. (2016). General and Industrial Management. Cambridge: Ravenio Books.

Grabe, W., \& Stoller, F. L. (2019). Teaching and researching reading. London: Routledge: Taylor \& Francis.

Harvey, S., \& Goudvis, A. (2017). Strategies that work: Teaching comprehension for understanding and engagement. United States of America: Stenhouse Publishers.

Hoerniasih, N. (2017). Faktor Pendukung Keberhasilan Pengelolaan Pusat Kegiatan Belajar Masyarakat ( PKBM ) "Bina Sejahtera" Desa Pinayungan. In Prosiding Seminar Nasional Pendidikan FKIP UNTIRTA (pp. 125-134).

Indriyani, I. (2017). Pengelolaan Taman Bacaan Masyarakat Berbasis Kekeluargaan dan Dampaknya Ter- 
Serafin Wisni Septiarti et al. / Journal of Nonformal Education 6 (1) (2020) 85-91

hadap Kemajuan Literasi Masyarakat. Universitas Negeri Semarang. Retrieved from http://lib. unnes.ac.id/29793/1/1201413078.pdf

Irianto, P. O., \& Febrianti, L. Y. (2017). Pentingnya penguasaan literasi bagi generasi muda dalam menghadapi MEA. In Proceedings Education and Language International Conference (Vol. 1, No. 1).

Karadeniz, A., \& Can, R. (2015). A Research on Book Reading Habits and Media Literacy of Students at the Faculty of Education. Procedia - Social and Behavioral Sciences, 174(1), 4058-4067. https:// doi.org/10.1016/j.sbspro.2015.01.1155

Lusiana, E., Yanto, A., Anwar, R. K., \& Komala, L. (2019). Taman Bacaan Masyarakat (TBMs): a global literacy potential in Bandung Smart City. In IOP Conference Series: Earth and Environmental Science (Vol. 248, No. 1, p. 012040). IOP Publishing. https://doi.org/10.1088/17551315/248/1/012040

Maulida, R. R. (2017). Peran Taman Bacaan Masyarakat (TBM) Warabal dalam Mengembangkan Minat Baca Anak Melalui Pendar dan Dongeng (Bachelor's thesis, UIN Syarif Hidayatullah Jakarta: Fakultas Adab dan Humaniora, 2017).

Oxenham, J. (2017). Literacy: writing, reading and social organisation. London: Routledge.

Pramudyo, G. N., Ilmawan, M. R., Azizah, B., Anisah, M., \& Deo, Y. (2018). Inovasi Kegiatan Taman Bacaan Masyarakat (TBM). Lentera Pustaka: Jurnal Kajian Ilmu Perpustakaan, Informasi Dan Kearsipan, 4(1), 29-38. https://doi.org/10.14710/ lenpust.v4i1.17332

Rahayu, R. R., Nurislaminingsih, R., Studi, P., Perpustakaan, S.-, Budaya, F. I., Diponegoro, U., ... Tembalang, K. U. (2019). Analisis Kegiatan Outing sebagai Media Promosi di Taman Bacaan Masyarakat (TBM) Warung Pasinaon
Kecamatan Bergas Kabuaten Semarang. Jurnal Ilmu Perpustakaan, 7(1), 261-270.

Rahayu, F. S. (2010). Manajemen Taman Bacaan Masyarakat sebagai UPaya Meningkatkan Budaya Literasi. Jurnal Eksistensi Pendidikan Luar Sekolah (E-Plus), 4(2), 164-174.

Rahmatillah, F. (2018). Strategi Pengelola Perpustakaan dalam Menumbuhkan Minat Baca Siswa di SMPN Palembang. UIN Raden Fatah Palembang. Retrieved from http://libraria.fppti-jateng.or.id/ index.php/lib/article/download/57/47

Rohman, I. N. (2019). Peranan Taman Bacaan Masyarakat (TBM) Luru Ilmu Untuk Menumbuhkan Minat Baca Masyarakat di Gersik, Kelurahan Sumber Mulyo, Kecamatan Bambanglipuro, Kabupaten Bantul. Jurnal Elektronik Mahasiswa Pend. Luar Sekolah, 8(8), 101-110.

Selden, R. (2016). Practising theory and reading literature: an introduction. London: Routledge: Taylor \& Francis.

Soh, K. L., Davidson, P. M., Leslie, G., \& Rahman, A. B. A. (2011). Action research studies in the intensive care setting: A systematic review. International Journal of Nursing Studies, 48(2), 258-268. https://doi.org/10.1016/j.ijnurstu.2 010.09 .014

Suwanto, S. A. (2017). Pengelolaan TBM Sebagai Sarana Meningkatkan Minat Baca Masyarakat. Anuva, 1(1), 19-32. https://doi.org/10.14710/ anuva.1.1.19-32

Tegmark, M. (2017). Life 3.0: Being human in the age of artificial intelligence. New York: Knopf.

Yunus, S. (2018). 8 Cara Jitu Mendirikan Taman Bacaan Masyarakat versi TBM Lentera Pustaka. Retrieved July 20, 2018, from https://www. jagatngopi.com/8-cara-jitu-mendirikan-tamanbacaan-masyarakat-versi-tbm-lentera-pustaka/ 